\title{
Development Of Writing Learning Model Using Process Approach In Class III Elementary School
}

\author{
Mursal, Syahrul R. \\ Universitas Negeri Padang \\ Mursalinmahyudinsyam@yahoo.com
}

\begin{abstract}
This research is caused by the low ability of students in writing. Students' writing is difficult to read. Writing the alphabet and numbers seems still not good and neat, this will hurt the students themselves. When examining the results of the exercise, the teacher has difficulty reading the writing of students, and as a result students get low scores. This type of research is field research to describe Indonesian learning activities from aspects of writing. Data collection used in this study, obtained from interviews, and documentation. The results showed that writing learning received less attention from the teacher which resulted in students' writing difficult to read.
\end{abstract}

Keywords-writing; elementary school; learning model; process approach

\section{INTRODUCTION}

Reading and writing are closely related and are the gateway to learning productivity in today's digital age. Governments, teachers and parents have a big role in the education of learners in Elementary School. With proper reading and writing materials, a conducive environment, and teachers with adequate educational qualifications, good reading and writing skills will help produce learners who perform well in other subjects (Amutha, 2015). Writing skills have an important role to increase the competence of learners, especially in the field of communication and interact with the environment (Javed, Juan, \& Nazli, 2013).

However, writing received less attention from teachers and parents of learners. The difficulties of learners in writing seem to be commonplace in the early phases of education. If allowed to continue, this will harm the students themselves.

Learners need to read a lot to improve their writing skills (DeMichele and Ozark, 2015). Learners in writing should be given a topic related to what is experienced (Hashemi and Mirzaei, 2015). Learners need to have an understanding and writing skills, and teachers should develop an appropriate and planned plan of writing learning with effective learning strategies. The support and guidance of teachers in writing is necessary for students to complete their tasks well (Ahangari, Hejazi, and Razmjou, 2014).

The effort of teachers in membelajarkan learners is an important part in achieving the success of the planned learning objectives of writing. One of the efforts is the selection of various models of learning. Appropriate learning model can increase the activity of learners in writing, and it is expected that teachers can choose various models of learning tailored to the level of development of learners. Some of the things that will be discussed in this paper are; (a) how is the writing activity activity in the third grade of elementary school? (b) what is the model of the learning approach to writing in the third grade of elementary school?

Writing can be regarded as a process or a result. Writing is an activity that someone does to produce a writing. Actually writing activities that produce a writing we often do, for example, record messages or write messages for friends.

Writing is to derive or represent graphic symbols depicting a language that a person understands, so that others can read the graphic symbols if they understand the language and graphic picture (Tarigan, 1998).

According Nurgiyantoro (2005) writing is an activity express ideas through the media language. Writing is a productive and expressive activity so the writer must have the ability to use vocabulary, grammar, and language structure.

Based on the opinion of the experts above it can be concluded that writing is an activity to paint the graphic symbol and pour ideas through the language media.

Students in elementary school are focused on reading and writing learning. Writing can be grouped into two, ie write the beginning and write further.

The type of writing outline is to write the beginning and write further. 1) Beginning writing begins by holding the right pencil. Level of beginning, writing activity is more dominated by things that are mechanical. Such mechanical activity may be; a good sitting posture in writing, how to hold a pencil / stationery, how to hold a book, and relax the 
hands by writing in the air. 2). Further writing consists of writing narrative, description, persuasion, argumentation, and exposition (Taufik, 2017).

From the above opinion can be concluded that the writing of the beginning of writing activities more dominated by things that are mechanical. While in writing further consists of writing narrative, description, persuasion, argumentation, and exposition.

Learning model is a guideline used by teachers or instructors to carry out teaching and learning activities, which includes the activities of teachers and learners with attention to the environment and facilities available in the classroom or place of learning.

The teaching model is designed to help learners develop thinking skills and gain an understanding of the shape of something or in the specific form of matter (Eggen, P, Don Kauchak, 2012). Joyce and Weil (2009) define the learning model is a plan or a pattern that is used as a guide in planning the learning in the classroom or learning in the tutorial and to determine the learning tools including in dthe nature of books, movies, computers, curriculum, and others. Each instructional model directs teachers or instructors in designing learning to help learners in such a way that the learning objectives are achieved (Joyce and Weil, 2009). Learning models are grouped into four clumps, and each clump consists of several models. The four clumps of the model are the information processing model family, the personal model family, the social family, and the behavioral system family clusters.

From the above point it can be concluded that the learning model is a conceptual framework describing a systematic procedure in organizing learning experiences for achieve specific learning objectives, and serve as a guide for instructional designers and teachers in planning and carrying out teaching and learning activities.

Writing in outline consists of writing a beginning and writing further. Beginning writing begins with an introduction to how to hold the correct pencil. The initial level is dominated by things that are mechanical. The mechanical activity in question can be; good sitting attitude, how to hold stationery, how to hold a book and relax your hands by writing in the air. Whereas in further writing consists of writing narration, description, persuasion, argumentation and exposition.

Approach to writing to primary school students is a process that is repeated. At the time the learners writes means a process is happening.Taufik (2017) states that the writing process there are three namely pre-writing, while writing, and post-writing. At the pre-writing stage learners do activities to find ideas. At the time of writing the learners spelled out the idea into written form. In post-writing, learners revision, edit and publish papers.

Pre-writing is the preparation stage. At this stage an author conducts various activities, such as finding ideas, determining titles, choosing the type of writing, creating a framework, and collecting materials. Writing ideas can come from experience, observation, reading material, and imagination. This activity can be carried out through various activities, for example reading books, newspapers, magazines, and the like. When writing. The writing stage begins by describing ideas into written form. The idea is expressed in sentence and paragraph form. Furthermore, the paragraphs are combined into one complete essay. This stage requires a variety of linguistic knowledge and writing techniques. Linguistic knowledge is used for word selection, language style determination, sentence formation, and compilation of essays. Post writing. Post writing consists of three, namely; revise, edit, and present.

\section{METHODS}

The research conducted is field research. This research is in the form of description as problem solving investigated by describing or describing the state of the object of research at the present time based on facts that appear as they are without intending to compare with the data added in the library. This study does not require a large population and sample. The results refer to respondents' answers.Data collection techniques used in this study, namely:

a. Interview, ie obtaining information for research purposes by way of question and answer. In this research interview is a process in collecting data for a research. Respondents in question are learners in class III Primary School

b. Documentation, which is looking for data about things or variables in the form of notes, books, and other sources. The data obtained in the study, analyzed qualitatively, in accordance with that proposed by Rochiati (2007) namely; data analysis begins with reviewing since data collection, until all data is collected. The data is based on the problem under study, followed by the presentation of data from each action. The data collection stage is as follows.

a. Reviewing the data that has been collected either through observation, field recording by transcripting the results of observation, selection of data, such as grouping data on the first and second cycle. Activities of data review carried out since the beginning of data collected.

b. Data reduction, including categorization and classification. All the collected data are selected and grouped according to research focus. The data has been separated and then selected which are relevant and which are not relevant. Relevant data are analyzed and which are not, discarded.

c. The presentation of data is done by organizing information that has been reduced. The data has been simplified grouped based on the problems studied, presented in the form of text or tables so as to facilitate the analysis.

d. Summing up the results of the study, this action is the final conclusion of the study. Activities are conducted in a way; review of field notes. 


\section{FINDING AND DISCUSSION}

The results of observations on the learning activities of Indonesian aspects of writing on Tuesday obtained the following matters; In the initial activity, the teacher greets the students, instructs the learners to keep everything that is not related to learning, praying. Then the teacher takes the Quran and instructs the learners to continue reading one verse before the lesson begins. This is done every day and learners simply read one verse in turn.

In the core activities, teachers instruct students to open LKS Indonesian language . Keep in mind that learning should be based on a theme, but still the implementation is done as usual, ie based on subjects. After that the teacher instructs the learner to read aloud in turn.

Each learner has a turn to read a paragraph. In the facial expressions of learners, it appears that the reluctance of learners to open LKS that less attract their attention. There are students who are less fluent in reading, but there are also students who can not wait to get a turn to read. There is no attention of teachers regarding the procedure of reading learners, whereas learners mostly read without regard to semicolon point.

After learners finished reading LKS, then teacher instruct students to answer LKS. When students do the LKS, teachers do another job on the teacher's desk. After the learner completes, the teacher proceeds by instructing the students to exchange the LKS with a classmate to check the answers that have been given.

The activities done on Friday are not much different on Tuesday. There is no change in the direction of learning to write to a better direction, where learners are left to write answers without any suggestions and inputs to the writing of learners.

When learners check each other's answers, many people complain that his friend's reply can not be read. The teacher simply orders that the unreadable text is blameworthy, without any solution to the improvement of the learner's writing. Especially when the teacher instructs the students to make up, then read the results of the essay to the front of the class. Sometimes learners themselves confused reading the results of writing made. The correct writing process gets less attention from the teacher, because the teacher thinks the correct learning of the writing procedure has been taught by the first and second grade teachers, and not the time to improve the writing to be neat.

Writing is an aspect of language skills that are productive. Productivity in writing skills requires students to skillfully utilize the structure of language so that the writing produced is interesting to read. However, this is still an obstacle because there are still many students who are less skilled in writing (Fitri, 2018). Writing is an activity of arranging or organizing thoughts, ideas, or ideas by using a series of sentences with integrated in written language (Jaya, 2013). Writing is basically an activity of processing the mind and communicating the results of thoughts in writing. Writing is also said to be the latest form of manifestation in aspects of language skills after reading. Therefore, writing has a higher level of difficulty compared to other language skills. To practice writing skills, a student must master all three other linguistic skills, namely reading, speaking, and listening (Hartidini, 2018).

Writing learning is not optimal also caused by low student interest in writing skills. Students' writing skills are still lacking, both from mastery of material, vocabulary, and punctuation, resulting in low ability of students in writing narratives (Hidayati, 2012). The low writing skills of students are also caused by a lack of practice and practice in writing. Skill writing does not come automatically, it is not easy to achieve, but must go through sufficient and regular practice and practice (Tatalia, 2015). Another fact which states that the ability to write is low is known from the teaching materials used by teachers and students are still based on textbooks, the book is the only source of information for learning (Lubis, 2015).

Based on some of the opinions above it can be concluded that writing learning in the third grade of elementary school has not run as expected. Writing learning cannot be taught one way, but is a repetitive process.

Learners need to read a lot to improve their writing skills (DeMichele and Ozark, 2015). Learners should be given a topic related to what is experienced (Hashemi and Mirzaei, 2015).

Learners need to have an understanding and writing skill, and teachers should develop a proper and planned plan of writing learning with effective learning strategies. The support and guidance of teachers in writing is necessary for students to complete their tasks well (Ahangari, Hejazi, and Razmjou, 2014). Teachers need to provide opportunities to learners to keep improving their writing by doing many exercises. Learners will reflect the writing, evaluate, and improve it themselves (Xin, 2007). Student self-confidence needs to be built in order to get better writing results (MacDuff, Khadija, \& Caroline, 2010). The teacher seeks to let learners be happy with what they have written and not embarrass their writing. They do not want others to read it. Learners should not be afraid, but give the learner the opportunity to appreciate the writing (Gair, 2015). During this writing-oriented writing of the results, not on the process and result in the quality of writing students who are still low. We recommend that teachers make learning writing a fun lesson, if learners have been motivated in learning to write, learners will know the error and fix it yourself. In this condition the teacher has been helped in correcting the mistakes of learners (Nurmilaakso, 2015). The result of the writing of the learner who has been made is examined by the teacher, then calculated how much time spent to write, whether sufficient or not (Gilbert \& Steve, 2010). Teachers need to provide sufficient time so that learners can complete the task of writing well (Noor \& Yusof, 2016). 
The teacher's effort in learners is an important part in achieving the success of the planned learning objectives of writing. One of the efforts is the selection of various models of learning. Appropriate learning model can increase the activity of learners in writing, and it is expected that teachers can choose various models of learning tailored to the level of development of learners.

\section{CONCLUSION}

Improving writing in the third grade of elementary school is no longer done. Previously there was an activity to improve the writing of students by specializing students to use continuous books. But the repair program of this writing does not go as it should. The teacher is more focused on mastering the subject matter than the improvement of writing, so that the program is gradually no longer applied.

Learning activity writing in grade III Primary School has not run well. A good teacher is expected to guide learners to achieve the expected learning objectives. The learning model should be varied, one of which uses a process approach. The author of this paper is limited to describe the condition of writing activity in the third grade of elementary school. Need further research using a process approach to improvement in learning.

\section{References}

Ahangari, S., Hejazi, M., \& Razmjou, L. (2014). The Impact of Scaffolding on Content Retention of Iranian PostElementary EFL Learners' Summary Writing. Procedia-Social and behavioral Sciences, 98, 83-89

Amutha \& M.J, Philomina. (2015). Diagnosis of Reading and Skills in Primary School Students. International Journal of English Language Teaching, 3(7), 1-7.

DeMichele, M., \& Ozark, L., (2015). Improv and Ink; Increasing Individual Writing Fluency With Collaborative Improv. International Journal of Education \& The Arts, 16(10), 1-25

Eggen, P \& Don K., 2012. Strategi dan Model Pembelajaran Mengajarkan Konten dan Keterampilan Berpikir. Jakarta: Indek

Fitri, A., R, Syahrul., \& Arief, E. (2018). Pengaruh Model Discovery Learning Berbantuan Media Audiovisual Terhadap Keterampilan Menulis Teks Eksposisi Siswa Kelas VIII SMP Negeri 31 Padang. Jurnal Pendidikan Bahasa dan Sastra Indonesia, 1(7), 125-132.

Gair, M. (2015). Slaying the Writing Monsters: Scaffolding Reluctant Writers through a Writing Workshop Approach. International Journal of Teaching and Learning in Higher Education, 27(3), 443-456

Gilbert, J., \& Graham, S., (2010). Teaching Writing to Elementary Students in Grades 4-6: A National Survey. The Elementary School Journal, 110(4),495-517

Hartidini, S., R, Syahrul \& R, Ellya. (2018). Pengaruh Strategi Pembelajaran Inkuiri Berbantuan Media Audiovisual Terhadap Keterampilan Menulis Karangan Argumentasi Siswa Kelas X SMA Negeri 2 Lengayang Kabupaten Pesisir Selatan. Jurnal Pendidikan Bahasa dan Sastra Indonesia, 1(7), 63-69.

Hashemi, Z., \& Mirzaei, T., (2015). Conversations of The Mind: The Impact of Journal Writing on Enhancing EFL Medical Students' Reflections, Attitudes, and Sense of Self. Procedia-Social and Behavorial Sciences, 199, 103-110

Hidayati, V., R, Syahrul \& Ratna, E. (20012). Peningkatan Kemampuan Menulis Narasi Ekspositoris Berbantuan Mind Mapping Siswa Kelas VII.2 SMP Negeri 2 Kamang Magek Kabupaten Agam. Jurnal Pendidikan Bahasa dan Sastra Indonesia, 1(1), 238-245

Javed, M., Juan, W X., \& Saima, N. (2013). A Study Students Assesment in Writing Skills of the English Language. International Journal of Instruction, 6 (2), 130-143

Jaya, S., R, Syahrul \& Ermanto. (2013). Peningkatan Keterampilan Menulis Puisi Melalui Media Gambar Siswa Kelas X.I SMA Negeri 2 Kota Sungai Penuh. Jurnal Bahasa, Sastra, dan Pembelajaran, 1(2), 87-95.

Joyce, B.,Weil, M., \& Calhoun, E.(2009). Models of Teaching.Terjemahan Oleh Achmad Fawaid \& Ateila Mirza. Yogyakarta: Pustaka Pelajar.

Lubis, M S., R, Syahru 1\& Juita, Novia. (2015). Pengembangan Modul Pembelajaran Bahasa Indonesia Berbantuan Peta Pikiran Pada Materi Menulis Makalah Siswa Kelas XI SMA/MA. Jurnal Bahasa, Sastra, dan Pembelajaran, 2(1), 16-28.

MacDuff, F., Al Hayki, Khadija., \& Linse, C. (2010).Using Progressive I-Can Statements to Promote Learner Confidence in Writing. English Teaching Forum. 4, 2-11

Noor, M., \& Yusof, N. M. (2016). Improving Process Writing with the Use Authentic Assesment. International Journal of Evaluation and Research In Education, 5(3),200-204

Nurgiyantoro, B. (2005). Sastra Anak, Pengantar Pemahaman Dunia Anak. Yogyakarta: Gadjah Mada University Press.

Nurmilaakso, M. (2015). How Children can Support Their Learningto Write and Read by Computerin the Early Years of School Journal of Teacher Education for Sustainability, 17(1), 99-107 
Tatalia, R. G., R, Syahrul \& Ermanto. (2015). Pengaruh Model PembelajaranKooperatifTipe STAD Berbantuan Pemetaan Pikiran (Mind Mapping) dengan Pertimbangan Motivasi Belajar Terhadap Kemampuan Menulis Teks Berita Siswa Kelas VIII SMP Negeri 1 Panti. Jurnal Bahasa, Sastra, dan Pembelajaran, 3(1),36-45

Taufik, T. (2017). Sumber Belajar Penunjang PLPG Unit I : Bahasa Indonesia. Jakarta: Kemendikbud Dirjen Guru dan Tenaga Kependidikan

Tarigan, D. (1998). Materi Pokok Pendidikan Bahasa Indonesia 1. Jakarta: Depdikbud.

Xin, Z. (2007). Reflective Thinking on Communicative Teaching in Writing. US-China Education Review, 4(5),19-25 